\title{
Citizen Engagement and the Challenge of Democratizing Health: An Italian Case Study
}

o envolvimento dos cidadãos e o desafio da democratização da saúde: um estudo de caso italiano

L'engagement des citoyens et le challenge de la démocratisation de la santé: une étude de cas italien

\section{Silvia Cervia}

\section{OpenEdition}

\section{Journals}

Electronic version

URL: http://journals.openedition.org/rccs/8309

DOI: $10.4000 /$ rccs.8309

ISSN: 2182-7435

\section{Publisher}

Centro de Estudos Sociais da Universidade de Coimbra

Printed version

Date of publication: 1 December 2018

Number of pages: 145-166

ISSN: 0254-1106

\section{Electronic reference}

Silvia Cervia, « Citizen Engagement and the Challenge of Democratizing Health: An Italian Case Study », Revista Crítica de Ciências Sociais [Online], 117| 2018, Online since 03 December 2018, connection on 20 April 2019. URL : http://journals.openedition.org/rccs/8309; DOI : 10.4000/rccs.8309 


\title{
SILVIA CERVIA
}

\section{Citizen Engagement and the Challenge of Democratizing Health: An Italian Case Study}

\begin{abstract}
Participatory practices, within broader processes of rescaling and governance, have been identified as the solution to the "democratic deficit" in healthcare. Conversely, scholars have underscored how these practices could well be used for a contrary purpose, particularly in a top-down process. The first part of this paper outlines a theory-based evaluation framework oriented towards the analysis of institutional practices fostering citizens' involvement in healthcare decision-making processes and how this involvement can act as a driver for the democratisation of the healthcare system. Following this interpretation, the second part of the paper analyses the new local governance structure adopted by Tuscany (Italy) in the healthcare sector, in particular the later stages of its adoption and diffusion and more than ten years after its institutionalisation. This leads us to identify certain crucial issues to be addressed when institutions promote re-visiting decision-making processes.
\end{abstract}

Keywords: citizen participation; democratisation; governance; healthcare; health policies; Italy.

\section{Introduction}

Modern times have witnessed the re-definition of decision-making processes in the healthcare system. Initially, these processes were built upon expertise and bureaucratic hierarchies, but they have become increasingly inclusive and shared, as shown by the new concept of governance and participatory regulations. The adoption of participatory practices has been identified by international organisations (WHO, 1986, 2002; WHO and UNICEF, 1978; Council of Europe, 2001) as a way - and perhaps the only way - to respond to the issue of the "democratic deficit" in the healthcare sector at the local level (Dickinson, 2004). ${ }^{1}$ Nonetheless, scholars have

\footnotetext{
${ }^{1}$ Dickinson defined the "democratic deficit" in healthcare as a combination of two processes: the crisis of legitimacy faced by the representative democracy and the traditional dominance of the medical profession in the sector (Freidson, 1973), which hindered alternative forms of public involvement in healthcare decision-making in order to monitor and control the activities of professional subsystems (Dickinson, 2004).
} 
cautioned about the risk of considering this process of redefining the structure of decision-making as a linear movement towards a fairer redistribution of decisional power in healthcare. Beginning with the seminal contribution of Sherry Arnstein (1969), many a scholar has pointed out the risk of the instrumental use of such a form of participatory decision-making to achieve non-democratic goals by manipulating public opinion (Maloff et al., 2000; Farrell, 2004; Bekkers et al., 2013). The literature highlights how this risk is reinforced by the ambivalent and multiform meaning of specific key concepts - such as citizen participation and governance - each of which identifies a process that could be embodied in very different and opposite forms, with very different and opposite outcomes (White, 1999). By analysing said literature, an antidote to the likely threat of such tendencies can be identified: the bottom-up process. When the re-definition of decision-making processes starts from the bottom, with the claims of civil society, the likelihood of an effective and more equal redefinition of decisional power is greater (Massey and Johnston-Miller, 2016). However, the process of renewal of decision-making processes promoted by the institutions themselves (top-down) must be duly considered, both for their consistency, in particular in Europe, and for the role that public institutions are called upon to play when such renewal processes affect collective goods (i.e. health) and services (i.e. healthcare). Indeed, scholars underline how public bodies are urged to play a greater role in contributing to the "publicness" of the public sector and to improve its accountability and responsiveness as the warrantor of equity and social justice (Martinelli, 2013; VV. AA., 2012).

This paper intends to offer a theory-based analysis of a concrete top-down process promoted in the healthcare sector. The aim is to better understand the conditions under which the renewal of local health governance (promoted by public bodies) can occur in an actual democratisation process.

In this first part, the article defines a theory-based evaluation framework in which to analyse end-user engagement in healthcare governance as a democratisation practice. Two main dimensions have been identified for consideration. The first refers to the logic of consequences (LoC), i.e. promoting a bold process that takes end-users from a passive role to an increasingly active one by giving them a participatory role in the re-design of public services (Mulgan, 2009). The second dimension deals with the logic of appropriateness (LoA), defined according to the international literature on civic engagement as a strategy for democratisation in the framework of Community Health Governance (Lasker and Weiss, 2003). 
Both dimensions will be operationalised in qualitative variables capable of detecting the constitutive elements and evaluating their function according to the aforementioned framework.

In the second part of the paper an empirical study is described - addressing the dimensions identified according to the LoA and LoC - whose aim is to investigate the scaling process in the selected case study, i.e. the Region of Tuscany, specifically its system of healthcare governance under the consortiums in the Società della Salute $(\mathrm{SdS})$, which comprise local healthcare centres/units and municipalities and have introduced forms of citizen participation in the $\mathrm{SdS}$ governance as a way to better respond to the social and health needs of the community. This seems to be an interesting case study, firstly, due to the nature of the institutional initiatives introduced by a top-down process, and secondly, given that it allows us to investigate the scaling processes that have received little attention in the literature (Albury, 2005; Bekkers et al., 2013). This part presents and discusses the outcomes of the analysis of the translational process and the diffusion and adoption processes of the last ten years.

In the final section, the paper highlights the issues that need to be addressed to better understand the dynamics of democratisation in health governance, especially the context in which socially innovative practices are institutionalised as top-down initiatives.

\section{Defining Participation as Democratisation}

In order to evaluate citizen engagement in healthcare governance as a democratisation process, it is important to briefly consider how, from a theoretical point of view, the broader horizons pushing for the inclusion of citizens in decision-making processes can be included in three compatible frameworks: technocratic, democratic-radical and strategic-residual. Faced with the dispersion of knowledge through multiple sources and the complexity of the process of understanding, which is typical of advanced societies, the technocratic approach proposes a governance framework based on the participation of all stakeholders and an efficient mechanism of interaction between expert knowledge and lay expertise (Prior, 2003; Sintomer, 2008). For the democratic-radicals, participatory practices become the strategy through which part of decision-making power is returned to citizens (Arnstein, 1969; Charles and DeMaio, 1993), while in the strategic-residual approach, participation becomes the strategy for resolving conflicts, without any implications for the re-distribution of decisional power (Connor, 1986). 
From the second perspective, the research assesses how citizen engagement in public decision-making affects the dynamics of social relations, including power relationships, and redefines the way in which public interest, priorities and policies are defined by including those previously excluded groups and individuals. Our approach stressed how the ethical dimension of public participation is very much related to social justice (Moulaert et al., 2005) and the logic of accountability, for its part, one of the lesser studied issues in social innovation (Anderson et al., 2014).

As emphasised by scholars, this affects different values that need to be linked and balanced, such as values related to the logic of consequence - efficiency, effectiveness, compliance - and values referring to the logic of appropriateness - trust, support and legitimacy (Bekkers et al., 2013).

Firstly, the consequences of citizen engagement in public decision-making can be analysed in terms of productivity and outcomes (Moore, 1995; Bason, 2010). However, as has already been noted, defining the value used to measure efficiency and effectiveness is no easy task (Bekkers et al., 2013). It is difficult to link the added value of this process to efficiency and outcome-effectiveness when one refutes public participation and, in particular, public participation in governance structure. To be taken into account is how involvement in decision-making processes "can therefore be seen as a symbolic act by which public managers and politicians try to achieve legitimacy and support for the work that they are doing" (ibidem: 12). This legitimacy is attainable in different ways, from manipulation to effective democratisation processes (Cervia, 2014) and calls to mind why citizens' engagement in governance structures needs to improve empowerment at individual and community level. This is the main goal of the collaborative form of governance introduced to indicate the specific management of citizen engagement and civil society representatives in public decision-making processes to support local empowerment and capacity building processes (Newman, 2001). Thanks to this concept, further developed by Ansell and Gash (2007), we can identify goals and tools suitable for defining the effectiveness and efficiency of a relational-decisional structure focused on local empowerment and capacity-building.

This framework points to the crucial role of the network in being effective, meaning that it cannot have a mere advisory role: collaboration involves bi-directional communication and must promote a circuit of mutual influence. This explains why it is crucial to consider how much the structure of a network and its operations can favour the sharing of responsibilities, even when the final say is in the hands of a public body (Freeman, 1997). 
These elements are embodied in collective-based decision-making. The contents of the decision cannot be defined through individual bilateral agreements or through decision-making paths based on power relationships and resources made available or potentially usable by individual partners; on the contrary, a collaborative approach is based on the institutionalisation of a collective decision-making process (Rummery, 2006) and on consensus among participants (Connick and Innes, 2003). For this to be possible, it is important that the decision-making process allow participants to develop a common reading and vision (Ansell and Gash, 2007).

The process leading to the decision must therefore be considered cyclical or reflective, in the sense that the architecture of the decision-making process should allow the network to learn from past experience (Huxham, 2003). For this reason, a necessary albeit insufficient condition is that the interaction between the subjects of the network be face-to-face in order to facilitate the removal of barriers and to facilitate the overcoming of shared prejudices (Ansell and Gash, 2007). Institutions are called upon to handle the proper use, application and respect of the principles and rules that they themselves have defined (Imperial, 2005; Fung and Wright, 2001) to foster the engagement of the participants and their sense of belonging and responsibility with respect to the final contents of the process.

Secondly, citizen involvement in healthcare governance must be considered from the LoA perspective, by considering the specific political and societal context in which governments have to operate (March and Olsen, 1989). As previously noted, when considering the appropriateness of innovation in the context in which it is being developed, we need to consider: a) institutional legitimacy and support; b) increasing citizen access, participation and empowerment, transparency, accountability and equality; c) the responsiveness of innovation with regard to the "publicness" of the public sector, thereby improving its legitimacy; d) its feasibility, with reference to the legal system and legal value (Bekkers et al., 2013). From a broader perspective, one must consider the innovation's level of appropriateness in terms of the democratic and legal values to be respected. The public value of the renewal of the governance structure in a participatory way is dependent on its legal feasibility and whether it respects specific legal values, given that governments are required to operate within the rule of law (Kelman, 2008; Korteland and Bekkers, 2008), as well as respond to the needs of society (Bekkers et al., 2013).

In light of the above factors, the issue of the legalistic culture of the public sector deserves attention. Firstly, the culture of standardisation and 
formalisation - a guarantee of free, universal and equal access - has to be tempered by the foundations of social innovation, which are inextricably linked to creativity and embeddedness (Bekkers et al., 2013). The legal competence and mandate of public institutions must also be considered, as they often come into conflict with the need for innovation across sectors, jurisdictions and mandates (Matthews et al., 2009).

From this point of view, however, the collaborative framework allows us to point out how the democratic and social legitimacy of a network is inextricably linked to its representativeness (Ansell and Gash, 2007). Once again, an extremely polymorphic concept comes into play, which can have statistical, corporate, interest-related or experiential representation, etc. Yet even in this case, the work of Ansell and Gash helps to identify a unique theory: the legitimacy of "mixed" participation, founded on both representation and the right to citizenship (uti singuli participation) and formalised in appropriate environments for participatory and deliberative democracy (with the integration of representative democracy). This form of participation can favour the process of empowerment (Fung and Wright, 2003).

However, the composition of a public body does not depend solely on the authorities but rather requires the free and voluntary involvement of private subjects. Therein lies the motivation for participation. The literature on this subject has determined that the asymmetries of power play an important role in reinforcing exclusion and removing marginal subjects from the network (Gray, 1989). The literature has also stressed the importance of private individuals' expectations and the ability of the structured system of participation to have a real impact on the contents of policies (Brown, 2000). ${ }^{2}$ The effectiveness of the system of participation is assessed according to the time and energy required (Bradford, 1998). The availability of resources is inversely related to the alternatives available to these stakeholders to influence the final decision. In the presence of a multitude of possibilities, private individuals prefer to resort to lobbying, preferential contacts, etc. (Khademian and Weber, 1997), rather than to pursue their goal(s) as part of a collaborative process (Logsdon, 1991).

The motivation to participate is also closely linked to the clarity of the mandate of the network that is also a crucial element in avoiding the risk of instrumentalisation. However, the literature on governance states that collaborative governance can only be referenced if it is limited to the

\footnotetext{
${ }^{2}$ This decreases considerably and ultimately disappears when network members suddenly perceive their participation as a mere ritual of participation (Futrell, 2003).
} 
political and programmatic sphere (Ansell and Gash, 2007) rather than organisational and/or management aspects.

The literature on participation also stresses the importance of a transparent public decision-making process, including deliberations, as a key element favouring citizens' control over the process (Coney, 2004; Rowe and Frewer, 2000).

These elements, linked to both the LoC and LoA, seem to generate trust and social capital both within and between the actors involved in the collaborative process (Lewis, 2010; Lewis et al., 2011). Respecting collaborative principles when defining the legal framework of the public decision-making renewal would represent a powerful tool for empowerment and the construction of social capital and would result in cohesion and capacity-building in any context (Ansell and Gash, 2007).

\section{Methods}

For the empirical part of this study, this framework has been translated into an analytical model to investigate the scaling process by analysing the dynamics caused by a renewal of healthcare decision-making over an extended period of time. The reform in Tuscany was promoted by a large body (at regional level) and concerned the local level. It defined a general framework expected to be applied and adapted to each context by the local authorities (municipalities and health authorities). The aim was to favour embeddedness, a key factor for the success of the project. Fifteen years have passed since the experiment was first launched in 2003 (in certain parts of the Region), and ten years since its institutionalisation in 2008, meaning that the scaling process can be analysed over an extended period of time.

The provisions introduced in the Regional Law are a point of departure to evaluate the positive and negative changes witnessed at the local level, depending on whether the regulatory provisions or the institutional practices identified at the local level were in line with the collaborative approach defined in the previous paragraph. The empirical base of this analysis consists of the Regional Law (Law no. 60/2008) and of the constituting Statute of each $\mathrm{SdS}$, of the internal regulations of the governing bodies, and the documents related to the Integrated Health Plan, a key document. Therefore, a content analysis was performed to identify the correspondence between the final document and the amendments or proposals defined by the bodies representing the citizens and local community.

The results of the analysis are depicted in Figure 1. The work of the local consortiums has been clearly shown, together with information on whether or not they introduced regulatory provisions or developed institutional 
practices that are more or less akin to the collaborative approach as opposed to the framework defined at regional level. The two analytical dimensions are represented along the two axes, indicating the position of the social innovation analysed in the present research.

However, a word of caution before discussing the results is fitting. To position the different experiences, the degree of adherence to the theory-based model was considered, with a more coherent form of adherence judged more favourably and vice-versa. The evaluation criteria shall be discussed further below.

In order to facilitate the interpretation of the graph, two orthogonal lines were used, representing the provisions of the Regional Law. In the upper right quadrant are those cases in which the LoC and LoA are reinforced by the provisions of the law; in the lower left quadrant are the SdS in which LoC and LoA are both reduced by the provisions of the law. In the upper left quadrant are the SdS that defined their network as more effective but less appropriate; and finally, in the lower right quadrant are the SdS that defined their network as less effective but more appropriate. Before proceeding, it is worth noting that the order of the SdS in the groups offers no interpretative value; of greater significance is the position of the group in the quadrant.

\section{Analysis}

\section{Regional level}

With regard to the LoA, the legal framework needs to be considered. The establishment of the SdS is an experiment introduced by the Integrated Social Plan 2002-2004, the Regional Health Plan 2002-2004 and the Regional Act for the establishment of the consortiums, adopted by the Regional Council with the Decision no. 155/2003. These Plans were subsequently and permanently transposed into the Regional Regulation on the Regional Health Service, by the Regional Law no. 40/2005 as amended by the subsequent Regional Law no. 60/2008. Already in the first phase of the experiment, the $\mathrm{SdS}$ were established to introduce change, necessary both in formal and substantive terms, the aim being to guarantee the quality and appropriateness, as well as the universality and fairness of the services on offer, through the greater involvement of the local communities. The establishing Decision no. 60/2002, adopted by the Regional Council, indicates how "change cannot be brought about solely by the law but must be tested and validated on the ground" (par. 1.6.2., p. 7). Subsequent provisions - Regional Law no. 40/2005 and Regional Law no. 60/2008 reinforced this idea, in addition to transforming the $\mathrm{SdS}$ from experimental 
bodies into an organizational solution, a point of reference for the entire regional socio-health system. The key act of these authorities was the Integrated Health Plan, through which and in accordance with which the guidelines provided at regional level, specific health and wellbeing objectives and specific services and forms of assistance were identified, defined and implemented to address the idiosyncrasies of the territory.

Unfortunately, the national regulatory framework has changed since the regional law's entry into force. With the financial law of 2010, the State ordered the abolition of all consortiums with the National Law no. 191/2009 (Art. 2, 186e), a decision declared binding even by the Constitutional Court, which rejected the appeal filed by the Region of Tuscany, with the judgment no. 326/2010. This situation led to a period of uncertainty, during which the SdS operated illegally and was forced to fight the administrative structure.

At first, the Region seemed willing to continue the journey undertaken with the reform. ${ }^{3}$ But it quickly yielded; indeed, at the end of 2013, the Regional Council asked the Local Assembly to shut down the consortiums by March 2014. ${ }^{4}$ With the Regional Laws no. 40/2014 and no. 45/2014 the Regional Council had therefore established that the SdS were not the only legitimate organisational and institutional structure. It also acknowledged that the districts could organise themselves through a simple agreement between the municipalities and the reference local health centres/units.

The Region proceeded by reorganising the health zones, thus introducing new elements in relation to one of the two constituent bodies of the consortiums and affecting the area of responsibility. According to the Regional Law no. 84/2015, the Region regulated the pooling of the local health centres/units, which fell from 12 to 3 in number, as well as the reorganisation of the zones/districts, which had to be reduced from 34 to 26.

Before examining how the timing of the diffusion of this institutional and organisational model was affected by such a complex and uncertain environment, a return to the analysis of the appropriateness of the network system is now called for, one which remained essentially unchanged from the initial trial phase to the implementation of Regional Law no. 60/2008.

The network of actors involved in the governance structure of the consortiums comprised not only the constituent bodies of the consortiums

\footnotetext{
3 The Decision no. 243/2011, adopted the 11 of April by the Regional Council, reiterated the Region's willingness to pursue this goal in spite of the uncertainty deriving from the government's regulations.

${ }^{4}$ With Resolution no. 219 of 18 December 2013, the Regional Council ordered the Local Assembly to submit a proposal to overturn the existing provisions regulating the consortiums by March 2014.
} 
(i.e. the municipalities and the local health centres/units of the zone/district), but also civil society, which was involved in the governance structure through two distinct bodies as provided by Article 71 undecies, with different set-ups and functions: the Participation Committee and the Third Sector Consultation Group. ${ }^{5}$

The Participation Committee is made up of representatives from the local community. It represents the users benefitting from the services, as well as the associations of protection and promotion and active support, provided they do not offer benefits. The Third Sector Consultation Group includes volunteer and third-sector organisations, which are present in situ and work in the field of health and social affairs.

The different composition of the bodies was useful for carrying out different tasks and at different times in relation to the decision-making process. The Committee intervened when drawing up guidelines and plans, it advanced proposals on programming and general governance and provided an opinion on the proposed Integrated Health Plan (PIS), the evaluation of service provision or, generally, the respect for citizens' rights and their dignity. The Consultation, on the other hand, only participated in the translation phase of the direction and guidelines of specific projects for the Integrated Health Plan. The members of the two bodies participated in the appointment of an Assembly. Members are appointed according to the criterion of representation of the local community.

As for the LoC, it is worth emphasising that according to the regulation, the Committee was assigned an essentially advisory role, ${ }^{6}$ whereas the Consultation was a group where plans were put together. In addition to examining the various regulations, it will be interesting to see how these roles were translated and if the practices developed within the consortiums led to their taking on a more or less cogent role.

The Regional Law was silent on the method of participation, on how to put together the decisions of the various bodies and on the facilities available for the organisation and operation of the bodies. There were also few indications about training. The Committee could access epidemiological statistical data relating to activities constituting the reference

\footnotetext{
${ }_{5}$ Regional Law no. 60/2008 also contemplated the creation of another tool for the local community, the so-called Agora della Salute. These agencies were not included in the government network and have therefore been excluded from our analysis.

${ }^{6}$ It is worth noting that in the transition from trial period to institutionalization, there was a far from negligible reduction in the Committee's role. Indeed, in the experimental phase, if the government body dared to diverge from the opinion expressed by the Committee, it had to provide explicit reasons for its decision.
} 
framework for health and social operations in the district/zone. It could also request that the Directors of the $\mathrm{SdS}$ provide specific analyses. This put the Committee in a privileged position, from which it could control the preparatory phase of the decision-making process, i.e. reading and interpreting the needs of the local community and identifying priorities.

As is evident, the regulation dedicated to "forms of participation" was rather "simplistic". Indeed, the text merely defined a sort of mesh system in which local actors were called upon to define the "rules of the game" that best fit each context. This is a feature that gives rise to two different scenarios. On the one hand, it seems to pervade the embedded nature of governance, which must be intrinsically "engrained", "rooted", or "incorporated" in the broader social context that, in various ways, favours, models and binds governance, leaving open the possibility of specific definitions that adapt the rules and processes to the characteristics of each local context (Moini, 2012). But this freedom can also be translated into a boomerang that backfires and returns as a form of manipulation and exploitation. Our examination of the institutional translational process will, through documented analysis, aim to verify the direction taken by the dissemination process within the regional political and institutional system and according to the theoretical coordinates identified in the section devoted to define participation as democratisation.

\section{Local level}

As of July 2017, nine years after the entry into force of the regulation that institutionalised the consortiums as a stable body for health governance in Tuscany, the reform is $60 \%$ operational. The problems encountered when establishing the consortiums and the few cases of dissolution are closely linked to the uncertainties arising from the situation in recent years. During the initial trial phase, in 2004, 18 SdS were established, involving a total of 158 municipalities and 10 local health centres/units, accounting for about $57 \%$ of the population. Following the entry into force of Regional Law no. 60/2008, the system was extended to another seven districts/ /zones; subsequently, following the events that overturned the legitimacy of the consortiums, $1 / 5$ of the $\mathrm{SdS}$ did not follow through with the project. Specifically, one consortium opted for dissolution (SdS Casentino in 2012), one was only registered after Regional Law no. 84/2015 was passed and therefore not set up (SdS Firenze Sud-est), and the remainder were meant to be set up in the period between 2008 and 2011, but were never established (with the exception of Alta Valdelsa, Pistoiese, Senese and Versilia). Therefore, there are currently 20 active SdS. 
By comparing the provisions defined at local level with the regulatory framework mapped out in the Regional Law no. 60/2008, we identified four groups. The provisions or the institutional practices developed at local level could be considered more or less coherent with the collaborative model. Of importance in the graph below (Figure 1) is the position of the group in the quadrant and not the position of each $\mathrm{SdS}$ within the group.

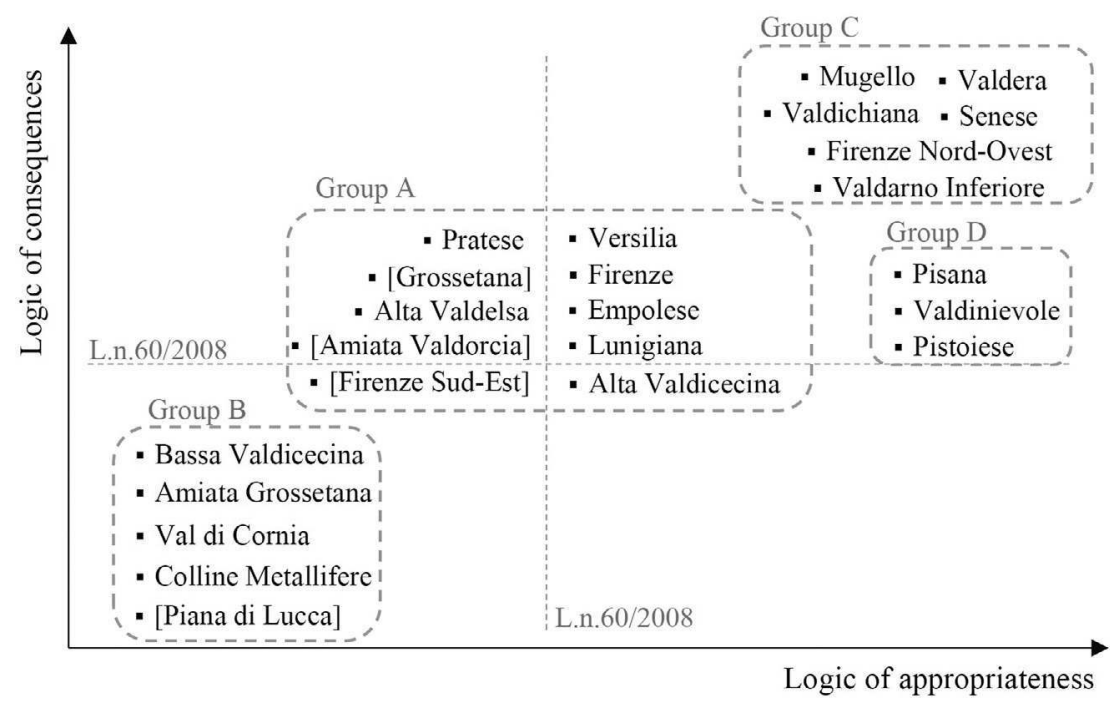

FIGURE 1 - Graph representing the results of the analysis

Source: Elaboration by the author.

Note: In square brackets the SdS that are no longer operational.

The group placed where the dotted lines meet (Group A) represents the modal group, which essentially proposes the regulation as is, without any particular changes. To keep track of some of the more interesting examples, the SdS Versilia, Firenze, Empoli and Lunigiana were placed in the upper right quadrant. This decision was made to enhance the status of the first two cases, where the members of the Committee are required to ensure the involvement of the relevant stakeholders in each sector and/or territorial area represented by activating information dissemination outlets to reach and engage the highest number of users possible (a critical point is the absence of elements that can turn the regulation into something more than just an invitation or wish). In the other two cases, one observes the possibility for the Committee and the Consultation Group to share 
and compare notes, thereby enhancing their unitary role (which is also present in two of the SdS belonging to Group C, i.e. SdS Valdichiana and Valdarno Inferiore).

The group located in the lower left quadrant (Group B) is represented by the $\mathrm{SdS}$ that neither set up the network provided for by the regulation in place at the time of their establishment nor introduced a sort of warranty for a quick set up. This occurred in roughly two out of ten cases, with more than four years going by before any appointments were made. In some cases, it is still not possible to find any rules or other documentation related to their operations (SdS Amiata Grossetana, Bassa Val di Cecina and Colline Metallifere). Of particular interest is that when looking at the appropriateness axis, Group B includes SdS that have extended the membership of the Committee to include federal and independent trade unions (Statute of Bassa Val di Cecina) and, in the case of the SdS Val di Cornia, industry trade unions, business associations and pensioners. In these cases, it is difficult to evaluate the effectiveness and efficiency of governance, which is why they have been positioned below the regulatory standard, also in terms of the LoC. In one case, that of Bassa Val di Cecina, additional details corroborate our decision. The SdS introduced a diminution of the role of the Committee, meaning that under the Statute, it could not access any statistical data, thus depriving it of any legitimacy from an autonomous point of view. This was countered by a strengthening of the role of the Consultation Group, which was granted an advisory role greater than that provided by the regulation, meaning it could be actively involved in the definition of the Health Profile and Integrated Health Plan and could consult the preparatory material and express recommendations before anything was approved. These methods have been criticised, as they increased the role and power of service providers at the expense of the end-users.

There are two groups in the mirror or upper right quadrant: Group $\mathrm{C}$ and Group D. Group C includes the SdS that, in line with the regulation, interpreted the construction of a decision-making network as mandatory, e.g. $\mathrm{SdS}$ Valdichiana, Senese, Firenze Nord-Ovest and, in particular, the SdS Mugello, whose Statute envisaged the compulsory establishment of the Participation Committee and the Third Sector Consultation Group "within six months of the entry into force of the Regulation". ${ }^{7}$ It is no coincidence that the SdS in

\footnotetext{
7 Provision included in the article 36 of the Statute establishing the SdS Mugello was approved on 23 December 2009 (archive document no. 13606). This provision was respected: the Participation Committee and the Third Sector Consultation Group was established on 30 June 2010, exactly six months and six days after the approval of the founding Statute.
} 
this group assigned a greater role to the local community's representative body (i.e. the Participation Committee) regarding the contents of the Integrated Health Plan. The Statutes of the SdS Valdichiana and Valdera, as well as that of Valdarno Inferiore ${ }^{8}$ envisaged that the Assembly would show just cause for all decisions deviating from the opinion expressed by the Committee.

Group D comprises the SdS that did not explicitly provide for a larger role given to the Participation Committee but that introduced practices and arrangements favouring the extension of their role and influence. This is the case of the SdS Valdinievole, where members of the Committee and Consultation Group could request to be present at any thematic discussions of the $\mathrm{SdS}$ in order to participate actively in the entire institutional programming process. When these discussions were held, the two participating bodies were allowed to select their own representatives (as per Committee and Consultation Rules). The Presidents of the two bodies had the right to participate in the meetings of the Assembly but did not hold voting rights. This was a permanent right of the SdS Valdinievole, Pisana and Pistoiese.

Interesting to note is that despite the lack of inverse correspondence between the degree of inclusion of the legitimacy of participation and the weakening of the role of the participating bodies (specifically the Committee) in Group B, in the upper left quadrant we find the SdS providing the most rigorous indications in terms of entitlement to participate. In most cases, this was a pre-dated determination of legitimate subjects, but in two cases, SdS Mugello (Group C) and SdS Pisana (Group D), lists were provided.

The logic of the quadrant allows for isolating another important dimension of appropriateness, that of the services provided by the SdS to the Committees and Consultations to assist them in their work. In certain cases (very few, in fact), providing assistance can also mean sending staff from the SdS. This is the case in Group C, for the SdS Valdichiana, Mugello and Firenze Nord-Ovest, as well SdS Pisana and Valdinievole in Group D, and SdS Empolese, Firenze and Versilia in the modal group. However, we must emphasize how this dimension of appropriateness expresses the most relevant degree of innovation in the shift from the experimental to the institutional phase. Unlike what occurred in the trial period, but also thanks to that very phase (as is apparent from the documentation consulted), it became important to provide minimum services and to ensure timely and congenial moments for the expression of opinions and

\footnotetext{
${ }^{8}$ It should be noted that in this case the regulation is contained in the Committee's Rules, a subordinate act to the Statute, which is approved by the Assembly.
} 
proposals, all of which was then translated into the statutory provisions applied after the 2008 reform.

To conclude the analysis, we must address the bottom-up dynamics promoted by the participating bodies of SdS Mugello, supported by the SdS Valdinievole, Valdarno Inferiore, Firenze Nord-Ovest and Firenze. This initiative was launched to encourage collaboration and a comparison between different consortiums in order to develop a common network and strategies. Thanks to this idea, on 16 March 2011, a Metropolitan Area Coordination Unit was established (the unit includes not just the SdS that promoted the initiative but also all SdS in the provinces of Florence, Prato, Pistoia and the district of Empoli). Unfortunately, despite such a potentially useful initiative, hopes were dashed with the introduction of financial austerity measures in 2010 and the ruling of the Constitutional Court, both of which created a climate of disorientation and uncertainty in which the most promising but also vulnerable incentives were encumbered.

\section{Conclusion}

A number of conclusions can be derived from the analysis presented above. Let us begin with a premise related to state and governance. The literature argues that the dominance of a legalistic culture can be seen as a constraint on the willingness of the public sector to innovate (Bekkers et al., 2013). Italy is seen as one of those countries with an entrenched legalistic tradition. In this context, the social innovation introduced by the Region of Tuscany seemed to strike the right balance between tradition and innovation, but it was not enough. It did not suffice that this innovation was introduced by law, thereby increasing its appropriateness, and that it was preceded by a trial period at the behest of the Region to ensure that the proposal would be adapted to the needs of the local communities. The reform was soon crushed by national law, which from one day to the next, rendered the entire process invalid. The decision undermined the appropriateness of the system and outlawed the institutional model originally chosen for the SdS. It profoundly, truly and symbolically discredited the entire proposal. Following the Constitutional Court's ruling, which confirmed the government's decision (and not that of the Region), no new $\mathrm{SdS}$ were established. The Region, after attempting to limit the damage, took a step back, and changed the SdS from the only body in charge of territorial socio-health planning and management to merely one of the possible options. The process of transposing the regulation and social innovation suffered a heavy setback between 2011 and 2012; indeed, very little documentation was produced by the consortiums after that period. 
Examining the analysis carried out on the other dimensions, one can only comment positively on how this attempt at innovation changed the role of the citizens, associations and volunteer organisations. Specifically, the Statutes reinforced the role and power of the representatives of the local community, in addition to bolstering efforts to establish a network (Metropolitan Area Coordination Unit) that would encourage collective learning and mutual contamination with good practices. Nevertheless, the governance architecture promoted by the Region of Tuscany was unable to overcome the past history of relations between the Third Sector, the local community and the institutions. Indeed, if we observe the geographic location of the $\mathrm{SdS}$, we will notice that there is a concentration of SdS belonging to the most developed territories (located on the Florence-Pisa line) in the upper right quadrant, where we have the only example of transversal contamination and coordination (the aforementioned Unit).

It can be seen, however, that this body was formed in the wake of a practice launched during the trial phase, during which the exchange between the stakeholders working for the same association in different territories led to greater comparison and contamination, and resulted in an isomorphism in the translational processes of the $\mathrm{SdS}$ belonging to those territories (contrary to what happened in other areas of Tuscany). An excellent example of this is the more important role assigned to the Committee in the overall decision-making process, reinforced by the regulations compelling the decision-making bodies of the consortiums to corroborate those decisions differing from the opinions received, and by regulations providing the resources needed for the proper functioning of the bodies, including the coordination of their agendas and timely planning, management and approval of documents and programmes.

In conclusion, it must be stressed how the arrangement of the case studies analysed along the rising diagonal axis represents the inextricable link between the two dimensions used for the present analysis and even seems to be a predictive reading tool for appreciating the possibilities for their development. Unfortunately, the sudden blow suffered by the process hindered innovation and prevented our analysis from observing the relations - and their dynamics - between the different groups, particularly those between Group C and D and those within Group A. Would we have witnessed the negative reinforcement of any inequalities or would the good practices developed by the best groups have contaminated the others too? And by virtue of what conditions/prerequisites/practices? The meaning to be drawn is that continued study of the more advanced stages of social innovation is needed to better understand these dynamics and to comprehend how the voice of 
the local community can (even if it is involved in a top-down participatory approach), in time, make itself heard within the space "permitted" and can go on to find new voices and new outlets.

Edited by Scott M. Culp

\section{References}

Albury, David (2005), "Fostering Innovation in Public Services”, Public Money \& Management, 25(1), 51-56.

Anderson, Tara; Curtis, Andrew A.; Wittig, Claudia (2014), Definition and Theory in Social Innovation. Krems: Danube University.

Ansell, Chris; Gash, Alison (2007), "Collaborative Governance in Theory and Practice”, Journal of Public Administration and Theory, 13, 1-29.

Arnstein, Sherry R. (1969), "A Ladder of Citizen Participation”, Journal of the American Institute of Planners July, 35(4), 216-224.

Bason, Christian (2010), Leading Public Sector Innovation. Bristol: Policy Press.

Bekkers, Victor; Tummers, Lars; Stuijfzand, Bobby Glenn; Voorberg, William (2013),

"Social Innovation in the Public Sector: An Integrative Framework", LIPSE Working Paper Series, no. 1.

Bradford, Neil (1998), "Prospects for Associative Governance: Lessons from Ontario, Canada”, Politics \& Society, 26, 539-573.

Brown, Ian (2000), "Involving the Public in General Practice in an Urban District: Levels and Type of Activity and Perceptions of Obstacles", Health and Social Care in the Community, 8(4), 251-259.

Cervia, Silvia (2014), La partecipazione dei cittadini in sanità. Italia ed Europa a confronto. Milano: Franco Angeli.

Charles, Cathy; DeMaio, Suzanne (1993), "Lay Participation in Health Care Decision-Making: A Conceptual Framework”, Journal of Health Politics, Policy and Law, 18(4), 881-904.

Coney, Sandra (2004), Effective Consumer Voice and Participation for New Zealand. A Systematic Review of the Evidence. New Zealand: New Zealand Guideline Group.

Connick, Sarah; Innes, Judith E. (2003), "Outcomes of Collaborative Water Policy Making: Applying Complexity Thinking to Evaluation”, Journal of Environmental Planning and Management, 46(2), 177-197.

Connor, Desmond M. (1986), “A New Ladder of Citizen Participation”, Constructive Citizen Participation, 14(2), 3-5.

Council of Europe (2001), The Development of Structures for Citizen and Patient Participation in the Decision-Making Process Affecting Health Care. Recommendation Rec (2000)5 And Explanatory Memorandum. Strasbourg: Council of Europe Publishing. 
Dickinson, Harley D. (2004), "Public Involvement in the Development of a Health Care Vision”, in Gregory P. Marchildon; Pierre-Gerlier Forest; Thomas Allan McIntosh (eds.), Changing Health Care in Canada: The Romanow Papers, vol. 2. Toronto: University of Toronto Press, 243-278.

Farrell, Christine (eds.) (2004), Patient and Public Involvement in Health: The Evidence for Policy Implementation. London: Department of Health.

Freeman, Jody (1997), "Collaborative Governance in the Administrative State”, UCLA Law Review, 45, 1-98.

Freidson, Eliot (1973), Profession of Medicine: A Study in the Sociology of Applied Knowledge. New York: Dodd Mead.

Fung, Archon; Wright, Erik Olin (2001), "Deepening Democracy: Innovations in Empowered Participatory Governance”, Politics \& Society, 29, 5-41.

Fung, Archon; Wright, Erik Olin (2003), Deepening Democracy: Institutional Innovations in Empowered Participatory Governance. London: Verso.

Futrell, Robert (2003), "Technical Adversarialism and Participatory Collaboration in the U.S. Chemical Weapons Disposal Program”, Science, Technology, \& Human Values, 28, 451-482.

Gray, Barbara (1989), Collaborating: Finding Common Ground for Multi-Party Problems. San Francisco: Jossey-Bass.

Huxham, Chris (2003), “Theorizing Collaboration Practice”, Public Management Review, 5, 401-23.

Imperial, Mark T. (2005), "Using Collaboration as a Governance Strategy: Lessons from Six Watershed Management Programs”, Administration \& Society, 37, 281-320.

Khademian, Anne M.; Weber, Edward P. (1997), "From Agitation to Collaboration: Clearing the Air through Negotiation", Public Administration Review, 57(5), 396-410.

Kelman, Steven (2008), “The 'Kennedy School' of Research on Innovation in Government", in Sandford S. Borins (ed.), Innovations in Government: Research Recognition and Replication. Washington, D.C.: Brookings Institute, 28-52.

Korteland, Evelin; Bekkers, Victor (2008), "Diffusion and Adoption of Electronic Service Delivery Innovations in Dutch e-Policing", Public Management Review, 10(1), 71-88. DOI: 10.1080/14719030701763195.

Lasker, Roz D.; Weiss, Elisa S. (2003), "Broadening Participation in Community Problem Solving: A Multidisciplinary Model to Support Collaborative Practice and Research", Journal of Urban Health, 80(1), 14-48. DOI: 10.1093/jurban/ jtg014.

Lewis, Jenny M. (2010), Connecting and Cooperating: Social Capital and Public Policy. Sydney: UNSW Press.

Lewis, Jenny M.; Considine, Mark; Damon, Alexander (2011), "Innovation Inside Government: The Importance of Networks”, in Victor Bekkers; Jurian Edelenbos; 
Bram Steijn (eds.), Innovation in the Public Sector: Linking Capacity and Leadership. Houndsmills: Palgrave McMillan, 107-133.

Logsdon, Jeanne M. (1991), "Interests and Interdependence in the Formation of Social Problem-Solving Collaborations", The Journal of Applied Behavioral Science, 27(1), 23-37.

March, James G.; Olsen, Johan P. (1989), Rediscovering Institutions: The Organizational Basis of Politics. New York: Fee Press.

Maloff, Bretta; Bilan, David; Thurson, Wilfreda (2000), "Enhancing Public Input into Decision Making: Development of the Calgary Regional Health Authority Public Participation Framework", Family \& Community Health, 23(1), 66-78.

Martinelli, Flavia (2013), "Learning from Case Studies of Social Innovation in the Field of Social Services: Creatively Balancing Top-Down Universalism with Bottom-Up Democracy”, in Frank Moulaert; Diana MacCallum; Abid Mehmood; Abdelillah Hamdouch (eds.), International Handbook of Social Innovation. Social Innovation, Collective Action and Transdisciplinary Research. Cheltenham: Edward Elgar, 346-360.

Massey, Andrew; Johnston-Miller, Karen (2016), “Governance: Public Governance to Social Innovation?”, Policy \& Politics, 44(4), 663-675.

Matthews, Mark; Lewis, Chris; Cook, Grahame (2009), Public Sector Innovation: A Review of the Literature. Canberra: ANAO - Australian National Audit Office. Moini, Giulio (2012), Teoria critica della partecipazione. Un approccio sociologico. Milano: Franco Angeli.

Moore, Mark H. (1995), Creating Public Value. Cambridge, MA: Harvard University Press.

Moulaert, Frank; Martinelli, Flavia; Swyngedouw, Erik; González, Sara (2005), “Towards Alternative Model(s) of Local Innovation”, Urban Studies, 42(11), 1969-1990.

Mulgan, Geoff (2009), The Art of Public Strategy. Oxford: Oxford University Press. Newman, Janet (2001), Modernising Governance: New Labour, Policy and Society. London: Sage.

Prior, Lindsay (2003), "Belief, Knowledge and Expertise: The Emergence of the Lay Expert in Medical Sociology", Sociology of Health and Illness, 25, 41-57.

Rowe, Gene; Frewer, Lynn J. (2000), "Public Participation Methods: A Framework for Evaluation", Science, Technology and Human Values, 25(1), 3-29. DOI: 10.1177/0162243903259197.

Rummery, Kirstein (2006), "Partnerships and Collaborative Governance in Welfare: The Citizenship Challenge”, Social Policy \& Society, 5, 293-303.

Sintomer, Yves (2008), “Du savoir d'usage au métier de citoyen?”, Raisons politiques, 31, 115-133.

VV. AA. (2012), Barriers to Social Innovation. Brussels: European Commission, DG Research. 
White, Deena (1999), "Consumer and Community Participation: A Reassessment of Process, Impact, and Value”, in Gary L. Albrecht; Ray Fitzpatrick; Susan C. Scrimshaw (eds.), Handbook of Social Studies in Health and Medicine. London: Sage, 465-480.

WHO - World Health Organization (1986), Ottawa Charter for Health Promotion. First International Conference on Health Promotion, Ottawa, 21 November. Accessed on 02.01.2018, at http://www.euro.who.int/_data/assets/pdf_file/0004/129532/ Ottawa_Charter.pdf.

WHO - World Health Organization (2002), Community Participation in Local Health and Sustainable Development. Approaches and Techniques. Geneva: World Health Organization.

WHO - World Health Organization; UNICEF - United Nations International Children's Emergency Fund (1978), Primary Heath Care. Report of the International Conference on Primary Health Care, Alma-Ata, USSR, 6-12 September. Geneva_WHO. Accessed on 02.01.2018, at http://apps.who.int/iris/bitstream/handle/10665/39228/9241800011. pdf? sequence $=1$ \&isAllowed $=y$.

Received on 27.02.2018

Accepted for publication on 01.08.2018

\section{Silvia Cervia}

Dipartimento di Scienze politiche, Università degli Studi di Pisa

Via Serafini 3, 56126, Pisa, Italia

Contact: silvia.cervia@unipi.it

\section{O envolvimento dos cidadãos $e$ o desafio da democratização da saúde: um estudo de caso italiano}

As práticas participativas, em contextos mais alargados de redimensionamento e governação, foram identificadas como sendo a solução para o "défice democrático" nos cuidados de saúde. Por outro lado, os académicos sublinharam que tais práticas podem muito bem ser utilizadas para fins opostos, nomeadamente em processos do topo para a base. A primeira
L'engagement des citoyens et le challenge de la démocratisation de la santé: une étude de cas italien Les pratiques participatives, dans des contextes plus élargis de redimensionnement et de gouvernance, furent identifiées comme étant la solution au "déficit démocratique" en matière de soins de santé. Par ailleurs, les académiques ont souligné que de telles pratiques peuvent fort bien être utilisées à des fins contraires, notamment dans des procédures partant du 
parte deste artigo apresenta um quadro de avaliação, baseado na teoria, orientado para a análise das práticas institucionais que promovem o envolvimento dos cidadãos nos processos decisórios, e como esse envolvimento pode funcionar como um impulsionador para a democratização do sistema de saúde. Na sequência de tal interpretação, a segunda parte do artigo analisa a nova estrutura de governação local adotada pela Toscana (Itália) no setor da saúde, designadamente as fases mais recentes da sua adoção e difusão, e mais de dez anos após a respetiva institucionalização. Isso leva-nos a identificar alguns aspetos cruciais a ter em conta quando as instituições promovem a reavaliação dos processos de tomada de decisão.

Palavras-chave: cuidados de saúde; democratização; governação; Itália; participação cidadã; políticas de saúde. sommet vers la base. La première partie de cet article présente un encadrement de l'évaluation, reposant sur la théorie, orienté par l'analyse des pratiques institutionnelles qui promeuvent l'engagement des citoyens dans les procédures de décision, tout autant que cet engagement peut fonctionner comme un moteur de la démocratisation du système de santé. Dans l'esprit de cette interprétation, la seconde partie de l'article se penche sur la nouvelle structure de gouvernance locale adoptée par la Toscane (Italie) dans le secteur de la santé, en particulier les phases les plus récentes de son adoption et de sa diffusion et plus de dix ans après ladite institutionnalisation. Cela nous conduit à identifier quelques points cruciaux dont il faut tenir compte lorsque les institutions promeuvent la réévaluation des processus de prise de décision.

Mots-clés: démocratisation; gouvernance; Italie; soins de santé; engagement des citoyens; politiques de santé. 
